\title{
Combined occurrence of chyloperitoneum and chylothorax after retroperitoneal surgery
}

\author{
G. Müns, S.I. Rennard, A.A. Floreani
}

Combined occurrence of chyloperitoneum and chylothorax after retroperitoneal surgery. G. Müns, S.I. Rennard, A.A. Floreani (OERS Journals Ltd 1995.

ABSTRACT: Chyloperitoneum is a rare complication of abdominal or retroperitoneal surgery, and the combined occurrence of chylothorax and chyloperitoneum has been reported in only a few cases.

We describe a case of this complication, which became clinically apparent 20 days after a Warren shunt operation. The large chylous effusion compromised breathing and required chest tube drainage, pleurodesis, medium chain triglyceride (MCT) diet, and, later, total parenteral nutrition (TPN). The patient made a full recovery on TPN for 5 weeks.

Eur Respir J., 1995, 8, 185-187.

\author{
*University of Nebraska Medical Center, \\ Dept of Internal Medicine, Pulmonary and \\ Critical Care Medicine Section, Omaha, \\ Nebraska, USA. \\ Correspondence: G. Müns, University of \\ Nebraska Medical Center, 600 S 42nd Street \\ Dept of Internal Medicine, Pulmonary and \\ Critical Care Medicine Section, Omaha, \\ NE 68198-5300, USA \\ Keywords: Chest tube drainage, chy- \\ loperitoneum, chylothorax, pleurodesis, \\ Warren shunt \\ Received: March 111994 \\ Accepted after revision July 281994
}

Combined occurrence of chyloperitoneum and chylothorax after abdominal or retroperitoneal surgery is a very rare condition [1-5]. We report a case of this complication, which developed 20 days after a Warren shunt operation.

\section{Case report}

The patient, a 34 year old white male, had a 15 year history of intermittent, but heavy, drinking. He had been hospitalized for alcoholic pancreatitis 2 yrs previously, and in the interim had developed liver cirrhosis with portal hypertension. Because of repeated bleeding from oesophageal varices, a distal splenorenal shunt (Warren shunt) was performed. The patient's preoperative chest $\mathrm{X}$-ray was normal. His postoperative course was initially unremarkable, and an abdominal ultrasound 5 days after surgery revealed a nodular liver, a patent shunt, and a moderate amount of ascites. On postoperative day 9, he was discharged.

Physical examination performed following hospitalization revealed a soft, slightly distended abdomen, and evidence of small amounts of ascites. The patient complained of a low grade fever since discharge, with temperatures approximately $38.0^{\circ} \mathrm{C}$. On postoperative day 20 , his weight was stable compared to previous visits, though more ascites was evident than on prior examinations. No edema was detected. Examination of the thorax revealed crackles on auscultation and dullness to percussion over the right lung base, while a chest radiograph suggested right basilar consolidation. Antibiotic therapy was initiated. A white blood count (WBC) was drawn and was 6.0 cells·nl-1. On day 25 after surgery, a chest radiograph was consistent with a large right pleural effusion and right lower lobe atelectasis. The patient's temperature was $37.6^{\circ} \mathrm{C}$, WBC 6.9 cells.nl ${ }^{-1}$, with $80 \%$ segmented neutrophils and $12 \%$ lymphocytes. Paracentesis was performed for diagnosis of peritonitis, and yielded a thick yellow fluid.

The patient was admitted to the hospital for treatment of peritonitis $v s$ bronchopneumonia. Examination of the peritoneal fluid showed a WBC of 678 cells $\mu \mathrm{l}^{-1}$, with $38 \%$ polymorphonuclear neutrophils, $54 \%$ lymphocytes, and $4 \%$ monocytes, and $4 \%$ mesothelial cells. Cultures were negative. Chest radiograph findings did not improve, and on postoperative day 32, a thoracocentesis was performed. The tan-coloured pleural fluid contained 2,889 white blood cells $\mu \mathrm{l}^{-1}, 19 \%$ polymorphonuclear neutrophils, $28 \%$ lymphocytes, $40 \%$ monocytes and histiocytes, $2 \%$ eosinophils, and $11 \%$ mesothelial and other cells. Lactate dehydrogenase (LDH) was 263 $\mathrm{U} \cdot l^{-1}$, glucose $115 \mathrm{mg} \cdot \mathrm{dl}^{-1}$, protein $4.9 \mathrm{~g} \cdot \mathrm{dl}^{-1}$, amylase $47 \mathrm{U} \cdot \mathrm{l}^{-1}$, $\mathrm{pH} 7.47$, cholesterol $82 \mathrm{mg} \cdot \mathrm{dl}^{-1}$, and triglycerides $586 \mathrm{mg} \cdot \mathrm{dl}^{-1}$. All cultures, including acid fast bacilli, were negative. Repeat evaluation of the peritoneal fluid revealed a cholesterol level of $51 \mathrm{mg} \cdot \mathrm{dl}^{-1}$ and triglycerides were $515 \mathrm{mg} \cdot \mathrm{dl}^{-1}$. Corresponding serum levels for cholesterol were $119 \mathrm{mg} \cdot \mathrm{dl}^{-1}$, triglycerides 71 $\mathrm{mg} \cdot \mathrm{dl}^{-1}$, and protein $6.6 \mathrm{~g} \cdot \mathrm{dl}^{-1}$. The patient was on a low protein, low sodium diet at this time.

The findings were consistent with a chylothorax, which was thought to be secondary to chyloperitoneum. The most likely cause of this chylous ascites was felt to be leakage caused by the patient's prior Warren shunt operation. A chest tube was placed, because of the large 
size of the chylous effusion, and medium chain triglyceride (MCT) diet via nasogastric tube was initiated. On the first day, 2,300 ml pleural fluid was drained, and more than $2,000 \mathrm{ml}$ on the second days. On postoperative day 35, pleural sclerosis therapy was performed (500 $\mathrm{mg}$ doxycycline in $30 \mathrm{ml}$ normal saline with lidocaine via chest tube). More than $1,800 \mathrm{ml}$ fluid was still drained daily, and thus total parenteral nutrition (TPN) was commenced on postoperative day 38 , and the pleural sclerosis repeated 2 days later. The drainage continued to decrease to less than $300 \mathrm{ml} \cdot$ day $^{-1}$, and 43 days after the initial shunt surgery the chest tube was removed. A chest radiograph showed only a small right pleural effusion. On postoperative day 47, the patient was discharged on TPN. He improved over the next weeks, with his ascites progressively decreasing, and his chest $\mathrm{X}$-ray findings remained stable. After 32 days on TPN, oral diets were commenced. The patient is now on his regular adjusted liver diet, remains stable, and has not reaccumulated peritoneal or pleural fluid.

\section{Discussion}

Postoperative chylous ascites has been observed after portal system decompression [1], retroperitoneal lymphadenectomy for genitourinary oncological surgery [2], abdominal aortic surgery [3], and after arthrodesis using an anterior approach to the spine [4]. Anatomically, chylous ascites can result from a leak in the thoracic duct, cisterna chyli, or its intestinal tributaries. The cisterna chyli is located at the level of the renal vessels, and is, thus, prone to injury in retroperitoneal surgery [5].

The exact incidence of combined occurrence of chylous ascites and chylothorax is not known. NIX et al. [6] reviewed 302 cases of chylous effusion: 123 patients with chylothorax, 146 patients with chylous ascites, and 33 patients with both conditions. In addition to this study, only a few case reports of combined occurrence of chylous ascites and chylothorax after retroperitoneal surgery have been published (table 1).

Diaphragmatic defects have been shown to be responsible for the occurrence of chylothorax secondary to chyloperitoneum. Congenital diaphragmatic weakness may result in invagination of the peritoneum causing blebs, which rupture secondary to increased abdominal pressure from coughing, straining, or ascites. This results in the movement of peritoneal fluid into the pleural cavity [5].

The diagnosis of chylothorax or chyloperitoneum is made by analysis of the milky fluid which consists mainly of triglycerides, and only small amounts of cholesterol and phospholipids. The triglyceride content is more than that of the plasma, with values $>110 \mathrm{mg} \cdot \mathrm{dl}^{-1}$ considered significantly elevated [10]. A lipoprotein analysis should be performed when there is doubt as to the diagnosis of chylothorax. The presence of chylomicrons in the pleural fluid confirms the diagnosis. The protein content of a chylous effusion or ascites is more than half of that normally found in plasma [11].

It is now generally agreed that the initial treatment of postoperative chylous effusions should be directed at reducing the flow of chyle, and therefore lymphatic pressure, as well as maintaining a proper nutrition. These goals can be achieved by MCT diets or low-fat elemental formulas $[2,9]$. MCTs are directly absorbed into the portal venous system, circumventing the intestinal lymphatics, although it has been shown that up to $20 \%$ of the triglycerides in chylous effusion in a patient on MCT have been medium chain triglycerides [12]. TPN is considered to be the appropriate alternative or next step-up in treatment [5]. Abdominal exploration for repair should be reserved for those patients who fail a prior trial of nutritional therapy, due to difficulties inherent in locating the sites of leakage [13]. Peritoneovenous shunting [8] should only be considered in intractable cases, because of complications, such as occlusion [11], sepsis, and intravascular coagulation, which can result following this procedure [13].

Thoracocentesis, chest tube drainage, and pleurosclerosis have been used effectively in the management of chylothoraces secondary to a thoracic aetiology. Whether these measures play the same role in the treatment of secondary chylothorax as they do in primary chylothorax is not known. They do not reduce the flow of chyle, but drainage can improve ventilation, and sclerosis of the diaphragmatic pleura may increase the barrier to leakage of ascitic fluid, thereby preventing reaccumulation of pleural fluid [14].

Our patient was treated with chest tube drainage for 11 days and received two intrapleural applications of

Table 1. - Case report of combined occurence of chylous ascites and chylothorax after retroperitoneal surgery

\begin{tabular}{|c|c|c|c|c|c|}
\hline $\begin{array}{l}\text { First author [Ref.] } \\
\text { Year }\end{array}$ & $\begin{array}{l}\text { Age } \\
\text { Yrs }\end{array}$ & Sex & Diagnosis & $\begin{array}{l}\text { Treatment of chylous } \\
\text { effusion }\end{array}$ & Outcome \\
\hline $\begin{array}{l}\text { BigLEy [7] } \\
1975\end{array}$ & 24 & M & $\begin{array}{l}\text { Teratocarcinoma } \\
\text { left testis }\end{array}$ & $\begin{array}{l}\text { Low fat diet } 4 \text { weeks, } \\
* *\end{array}$ & $\begin{array}{l}\text { NED after } 12 \\
\text { months }\end{array}$ \\
\hline $\begin{array}{l}\text { MiEDEMA [8] } \\
1978\end{array}$ & 25 & M & $\begin{array}{l}\text { Teratotcarcinoma } \\
\text { right testis }\end{array}$ & $\begin{array}{l}\text { TPN } 3 \text { weeks, } \\
\text { Denver shunt }\end{array}$ & $\begin{array}{l}\text { Died after } 12 \\
\text { weeks }\end{array}$ \\
\hline $\begin{array}{l}\text { DHARMAN [9] } \\
1984\end{array}$ & 47 & M & $\begin{array}{l}\text { Embronal cell carcinoma } \\
\text { left testis }\end{array}$ & $\begin{array}{l}\text { MCT diet } 6 \text { weeks, } \\
\text { thoracocentesis }\end{array}$ & $\begin{array}{l}\text { Complete } \\
\text { recovery }\end{array}$ \\
\hline $\begin{array}{l}\text { FERRIGINI [2] } \\
1985\end{array}$ & 30 & M & $\begin{array}{l}\text { Teratocarcinoma } \\
\text { right testis }\end{array}$ & $\begin{array}{l}\text { MCT died } 6 \text { weeks, } \\
* *\end{array}$ & $\begin{array}{l}\text { NED after } 2 \\
\text { yrs }\end{array}$ \\
\hline $\begin{array}{l}\text { JABOSE [5] } \\
1989\end{array}$ & $1 / 2$ & M & $\begin{array}{l}\text { Wilm's tumour } \\
\text { right kidney }\end{array}$ & $\begin{array}{l}\text { TPN, } \\
\text { chest tube } 24 \mathrm{~h}\end{array}$ & $\begin{array}{l}\text { NED after } 9 \\
\text { months }\end{array}$ \\
\hline
\end{tabular}

The interval between retroperitoneal surgery and chylous ascites was 2 days to 7 weeks. The onset of chylothorax was 1 week to 2.5 months after surgery. **: chest X-ray revealed small pleural effusions, that had not been tapped. NED: no evidence of disease; MCT: medium chain triglycerides; TPN: total parental nutrition; M: male. 
doxycycline. He was initially on MCT diet. After 3 days he was switched to TPN for 37 days, until full recovery.

In conclusion, the combined occurrence of chylothorax and chyloperitoneum is a very rare complication of retroperitoneal surgery. Medium chain triglycerides or total parental nutrition are simple and effective treatments of postoperative chylous effusion, but chest tube drainage and pleural sclerosis might also be helpful in the management of this condition. Surgical treatment should be reserved for patients in whom other measures have failed.

\section{References}

1. Maywood BT, Golstein L, Busuttie RW. Chylous ascites after a Warren shunt. Am J Surg 1978; 135: 700-705.

2. Ferrigini RG, Novicki D. Chylous ascites complicating genitourinary oncological surgery. J Urol 1985; 134: 774-776.

3. Williamson C, Provan JL. Chylous ascites following aortic surgery. Br J Surg 1987; 74: 71-72.

4. Shen YS, Cheung CY, Nilsen PT. Chylous leakage after arthrodesis using anterior approach to the spine. J Bone Joint Surg Am 1989; 71: 1250-1251.

5. Jabose S, Kogan S, Berezin S, et al. Combined occurrence of chyloperitoneum and chylothorax after surgery and chemotherapy for Wilms' tumor. Cancer 1989; 64: 1790-1795.

6. Nix JT, Albert M, Dugas JE, Wendt DL. Chylothorax and chylous ascites: a study of 302 selected cases. Am J Gastroenterol 1957; 28: 40-55.

7. Bigley HA, Jr, Chenault OW Jr, Chylous ascites following retroperitoneal lymphadenectomy. J Urol 1975; 114: 948-950.

8. Miedema EB, Bissada NK, Finkeiner AE, Casali RE. Chylous ascites complicating retroperitoneal lymphadenectomy for testis tumors: management with peritoneovenous shunting. J Urol 1978; 120: 377-378.

9. Dharman K, Temes SP, Wetherell FE, Kendrick M. Chyloperitoneum chylothorax: a combined rare occurrence after retroperitoneal lymphadenectomy and radiotherapy for testis tumor. J Urol 1984; 131: 346-347.

10. Light RW. In: Pleural Diseases. 2nd edn. Philadelphia; Lea \& Febiger, 1990; pp. 272-278.

11. Lessre G, Bruno SM, Enselberg K. Chylous ascites: newer insights and many remaining enigmas. Arch Intern Med 1970; 125: 73-77.

12. Jensen GL, Mascioli EA, Meyer LP, et al. Dietary modification of chyle composition in chylothorax. Gastroenterology 1989; 97: 761-765.

13. Unger SW, Chandler JG. Chylous ascites in infants and children. Surgery 1983; 93: 455-461.

14. Moss R, Hinds S, Fedullo AJ. Chylothorax: a complication of the nephrotic syndrome. Am Rev Respir Dis 1989; 140; 1436-1437. 